\title{
Piotr Bolibok
}

\section{ZADŁUŻENIE GOSPODARSTW DOMOWYCH A DYNAMIKA WYDATKÓW KONSUMPCYJNYCH W KRAJACH OECD PO WYBUCHU KRYZYSU FINANSOWEGO}

\section{Wprowadzenie}

W ciągu kilku dekad poprzedzających wybuch globalnego kryzysu finansowego większość gospodarek na świecie odnotowała znaczący wzrost zadłużenia w każdym z sektorów instytucjonalnych. Podczas gdy główny nurt dyskusji ekonomicznych i literatury przedmiotu koncentruje się na problemach związanych z długiem publicznym, zdecydowanie mniej miejsca poświęcane jest zagadnieniom długu prywatnego, w szczególności sektora gospodarstw domowych ${ }^{2}$. Tymczasem wysokie zadłużenie gospodarstw domowych ma poważne implikacje makroekonomiczne przejawiające się w szczególności w zwiększonej wrażliwości na wahania stóp procentowych, dochodów czy cen aktywów. Może ono stać się również bezpośrednim źródłem negatywnych szoków dla poszczególnych gospodarek ${ }^{3}$.

Skłonność gospodarstw domowych do zaciągania zobowiązań jest ściśle powiązana z poziomem rozwoju gospodarczego, stąd ich najwyższe zadłużenie odnotowuje się w krajach rozwiniętych ${ }^{4}$. Poziom zadłużenia gospodarstw domowych w poszczególnych krajach jest jednak silnie zróżnicowany, odzwierciedlając stopień rozwoju systemu finansowego, procesy demograficzne, skłonność społeczeństwa do oszczędzania i zadłużania się, rozwiązania systemu emerytalnego i zabezpieczenia społecznego oraz sytuację na rynku nieruchomości ${ }^{5}$. W większości krajów główną składową

1 Dr Piotr Bolibok, Katedra Bankowości i Finansów, Wydział Nauk Społecznych, Katolicki Uniwersytet Lubelski Jana Pawła II.

2 T. Gruszecki, Świat na długu, Wydawnictwo KUL, Lublin 2013, s. 69-72.

G. Debelle, Household debt and the macroeconomy, „BIS Quarterly Review” March 2004, s. 51-64.

„BIS Statistical Bulletin” June 2016, s. 259.

C. André, Household debt in OECD countries: stylised facts and policy issues, „OECD Economic Department Working Papers” 2016, No. 1277, s. 6. 
zadłużenia gospodarstw domowych stanowią kredyty mieszkaniowe ${ }^{6}$. Oprócz malejących stóp procentowych i liberalnej polityki kredytowej banków komercyjnych zwiększony popyt na te kredyty wynikał z czynników demograficznych (wchodzenie pokoleń wyżu demograficznego w okres wieku średniego) oraz fiskalnych (ulgi w podatku dochodowym z tytułu wydatków na obsługę zadłużenia) ${ }^{7}$.

Po wybuchu kryzysu w wielu krajach rozwiniętych odnotowano wyraźny spadek dynamiki popytu konsumpcyjnego, który poza wzrostem ryzyka utraty pracy i dochodów można przypisać nadmiernemu zadłużeniu znacznej części gospodarstw domowych ${ }^{8}$ oraz podejmowanym próbom jego redukcji ${ }^{9}$.

Celem artykułu jest weryfikacja empiryczna zależności występujących pomiędzy dynamiką wydatków konsumpcyjnych a zadłużeniem gospodarstw domowych w krajach OECD po wybuchu globalnego kryzysu finansowego. Dotychczasowe badania tego zagadnienia prowadzone były odrębnie dla poszczególnych rynków krajów rozwiniętych (zwłaszcza Stanów Zjednoczonych), podczas gdy w niniejszym opracowaniu podejmuję próbę jego rozpoznania w szerszym kontekście międzynarodowym.

Poza wprowadzeniem artykuł składa się z czterech części. W części drugiej dokonałem przeglądu opublikowanych wyników badań dotyczących zależności zachodzących pomiędzy zadłużeniem a dynamiką wydatków konsumpcyjnych gospodarstw domowych po wybuchu globalnego kryzysu finansowego. Część trzecia poświęcona została przedstawieniu metodyki badania, w tym wyprowadzonej hipotezy badawczej oraz wykorzystanych metod i źródeł danych. Wyniki badań przedstawiłem w części czwartej. Artykuł zamyka podsumowanie zawierające reasumpcję najważniejszych wniosków wynikających z przeprowadzonych analiz oraz sugestie dotyczące kierunków dalszych badań podjętego zagadnienia.

6 D. Finocchiaro et al., Household indebtedness, house prices and the macroeconomy: a review of the literature, „Sverige Riksbank Economic Review” 2011, Vol. 1, s. 6-28.

7 Zob. S.G. Cecchetti et el., The real effects of debt, „BIS Working Papers” 2011, No. 352, s. 8 oraz E. Bogacka-Kisiel, Finanse osobiste. Zachowania - Produkty - Strategie, Wydawnicto Naukowe PWN, Warszawa 2012, s. 157.

8 Zob. K. Dynan, Is a household debt overhangholding back consumption?, „Brookings Papers on Economic Activity" 2012, s. 299-362.

9 R. Glick, K.J. Lansing, U.S. household deleveraging and future consumption growth, „FRBSF Economic Letter" 2009, No. 16, s. 2. 


\section{Przegląd literatury}

W warunkach zmienności dochodów wykorzystanie długu pozwala gospodarstwom domowym na wygładzanie ścieżki konsumpcji ${ }^{10}$. Umożliwia ono również poniesienie większych wydatków i zaspokajanie w szerszym zakresie potrzeb wyższego rzędu niż byłoby to możliwe w oparciu o bieżące dochody, a także bardziej elastyczne reagowanie na zdarzenia losowe ${ }^{11}$. Zdaniem M. Wachowskiego zadłużanie się stało się w dzisiejszych czasach „warunkiem rozwoju” gospodarstw domowych ${ }^{12}$. Jak jednak stwierdza O. Sroczyński, swoista „kultura zadłużenia”, będąca podstawą konsumpcjonizmu współczesnych społeczeństw demokratycznych, stanowi jednocześnie główną przyczynę ich obecnych problemów gospodarczych. Z jednej strony bowiem dług umożliwia ponoszenie wyższych wydatków konsumpcyjnych, z drugiej zaś zbyt wysoki poziom zadłużenia i konieczność ponoszenia sztywnych wydatków związanych z jego obsługą mogą w długim okresie oddziaływać negatywnie na efektywny popyt konsumpcyjny.

Jak stwierdzają R. Glick i K.J. Lansing, powszechne zadłużanie się gospodarstw domowych w USA od lat 80. XX w. do wybuchu kryzysu finansowego pozwalało wydatkom konsumpcyjnym rosnąć $w$ tempie wyższym niż dochody rozporządzalne, co stanowiło istotną siłę napędową wzrostu gospodarczego ${ }^{13}$. W miarę wzrostu zadłużenia jego pozytywne efekty mogą jednak zanikać. Wyniki badań obejmujących 18 krajów OECD w okresie 1980-2006 przeprowadzonych przez Cecchettiego et al. wskazują, że po przekroczeniu progu 85\% PKB zadłużenie gospodarstw domowych wywiera negatywny wpływ na procesy wzrostu gospodarczego ${ }^{14}$.

Badania przeprowadzone w USA przez S.R. Bakera wykazały, że silnie zadłużone gospodarstwa domowe są bardziej wrażliwe na szoki dochodowe, co wynika głównie z ograniczonej płynności i zdolności do zaciągania dalszych zobowiązań. Wzrost relacji zadłużenia do aktywów o jedno odchylenie standardowe prowadzi przeciętnie do zwiększenia elastyczności dochodowej konsumpcji o blisko $25 \%{ }^{15}$. Według szacunków tego autora odnotowany w latach 2007-2009 spadek konsumpcji

10 S.G. Cecchetti et al., op.cit., s. 3.

11 C. Bywalec, Ekonomika i finanse gospodarstw domowych, Wydawnictwo Naukowe PWN, Warszawa 2012, s. 207-208.

12 M. Wachowski, Wybrane aspekty zadłużenia gospodarstw domowych $w$ Polsce $w$ latach 2005-2012, „Marketing i Rynek” 2015, nr 2, s. 151.

13 R. Glick, K.J. Lansing, op.cit., s. 1.

14 S.G. Cecchetti et al., op.cit., s. 3.

15 S.R. Baker, Debt and the consumption response to household income shocks, „SSRN Research Paper” 2014, No. 2541142, s. 1-46. 
był o blisko $20 \%$ silniejszy niż gdyby gospodarstwa domowe utrzymywały stopień zadłużenia na poziomie z początku lat 80 .

Z kolei według A. Aladangady’ego gospodarstwa domowe przeznaczające znaczną część swoich dochodów na obsługę zadłużenia miały szczególnie wysoką skłonność do konsumpcji finansowanej w oparciu o majątek w postaci nieruchomości. Popyt konsumpcyjny uzależniony jest nie tylko od majątku, ale również posiadanych zabezpieczeń spłaty zobowiązań ${ }^{16}$.

Do podobnych wniosków doszli też Mian et al., wskazując, że źródłem dysproporcji terytorialnych w skali spadków konsumpcji w USA była znacznie wyższa marginalna skłonność do konsumpcji finansowanej w oparciu o majątek w postaci nieruchomości na obszarach zamieszkanych przez uboższe i bardziej zadłużone gospodarstwa domowe ${ }^{17}$.

Również badania przeprowadzone przez K. Dynan wykazały, że nadmierne zadłużenie przyczyniło się do osłabienia popytu konsumpcyjnego. Silnie zadłużone gospodarstwa domowe właścicieli nieruchomości odnotowały w latach 2007-2009 wyższe spadki wydatków konsumpcyjnych niż pozostałe, pomimo relatywnie mniejszych zmian w wartości aktywów netto. Można zatem wnioskować, że zadłużenie wpływa na konsumpcję w znacznie większym stopniu, niż może to być wyjaśnione samym efektem majątkowym ${ }^{18}$.

Podobnych wniosków dostarczają również badania przeprowadzone w Europie. Według P. Bunna silnie zadłużone gospodarstwa brytyjskie w okresie kryzysu ograniczyły wydatki w znacznie większym stopniu niż te o niższym stopniu zadłużenia ${ }^{19}$, co wynikało zarówno z zaostrzenia kryteriów udzielania nowych kredytów, jak i obaw konsumentów o zdolność do prawidłowej obsługi zadłużenia w przyszłości.

Badając rynek norweski, Yao et al. stwierdzili, że zadłużenie gospodarstw domowych, zwłaszcza z tytułu kredytów mieszkaniowych, ma istotne znaczenie dla dynamiki popytu konsumpcyjnego ${ }^{20}$. Finansowanie zakupu nieruchomości długiem prowadzi bowiem do wzrostu marginalnej skłonności do konsumpcji zarówno z dochodów, jak i majątku, co wynika z mniejszej możliwości zaciągania dalszych zobowiązań oraz ograniczonej płynności nieruchomości.

16 A. Aladangady, Homeowner balance sheets and monetary policy, „Finance and Economics Discussion Series Working Paper" 2014, No. 2014-98, s. 1-40.

17 A. Mian et al., Household balance sheets, consumption, and the economic slump, „The Quarterly Journal of Economics" 2013, Vol. 128(4), s. 1687-1726.

18 K. Dynan, op.cit., s. 299-362.

19 P. Bunn, Household debt and spending, „Quarterly Bulletin” 2014, Q3, Bank of England, London, s. 305.

20 J. Yao et al., Housing, debt and the marginal propensity to consume, „Norges Bank Research Paper” 2015, s. 1-38. 
Analogiczne reakcje duńskich gospodarstw domowych stwierdzili Lau Andersen et al. ${ }^{21}$ Po 2007 r. silnie zadłużone gospodarstwa domowe zmniejszyły bowiem wydatki konsumpcyjne bardziej niż te mniej zadłużone. Jak wskazują wymienieni autorzy, zjawisko to wynikało przede wszystkim z konieczności skorygowania wysokości poziomu wydatków, który przed wybuchem kryzysu został „wywindowany” za pomocą długu do wielkości niemożliwej do utrzymania w długim okresie ${ }^{22}$.

\section{Metodyka badania}

Przeprowadzony przegląd literatury przedmiotu wskazuje na potencjalnie negatywny wpływ wysokiego zadłużenia na dynamikę popytu konsumpcyjnego w sektorze gospodarstw domowych krajów rozwiniętych po wybuchu globalnego kryzysu finansowego. Pozwala to na sformułowanie następującej hipotezy badawczej:

H1: Zadłużenie sektora gospodarstw domowych w krajach OECD po wybuchu globalnego kryzysu finansowego wywiera negatywny wpływ na tempo wzrostu ich wydatków konsumpcyjnych.

W celu zweryfikowania postawionej hipotezy została przeprowadzona analiza regresji liniowej tempa wzrostu wydatków sektora gospodarstw domowych względem tempa wzrostu dochodów rozporządzalnych netto (podstawowej determinanty popytu konsumpcyjnego) oraz poziomu zadłużenia i długoterminowych stóp procentowych w krajach OECD w okresie 2008-2014. Ujęcie w modelu długoterminowych stóp procentowych podyktowane zostało faktem, iż podstawową składową zadłużenia gospodarstw domowych w badanych krajach są zobowiązania $\mathrm{z}$ tytułu kredytów mieszkaniowych, które - jak wykazują wyniki badań przedstawionych w punkcie pierwszym - wywierają istotny wpływ na kształtowanie się popytu konsumpcyjnego. Skonstruowany model regresji liniowej przyjął następującą postać:

$$
\widehat{C A G R_{i t}}=\alpha_{0}+\alpha_{1} D I A G R_{i t}+\alpha_{2} D_{-} N D I_{i t}+\alpha_{3} L T I R_{i t}+\varepsilon_{i t}
$$

gdzie:

$C A G R_{i t}$ - tempo wzrostu finalnych wydatków konsumpcyjnych w kraju $i \mathrm{w}$ roku $t \mathrm{w} \%$, $D I A G R_{i t}$ - tempo wzrostu dochodów rozporządzalnych netto w kraju $i \mathrm{w}$ roku $t \mathrm{w} \%$,

21 A. Lau Andersen et al., Household debt and consumption during the financial crisis: Evidence from Danish micro data, „Danmarks Nationalbank Working Papers” 2014, No. 89, s. 1-30.

22 Ibidem, s. 7. 
D_NDI ${ }_{i t}$ - relacja całkowitego zadłużenia do dochodów rozporządzalnych netto $\mathrm{w}$ kraju $i \mathrm{w}$ roku $t \mathrm{w} \%$,

$L_{T I R}$ - przeciętny poziom długoterminowych stóp procentowych w kraju $i \mathrm{w}$ roku $t$ $\mathrm{w} \%$,

$\varepsilon_{i t} \quad-$ składnik losowy.

Kierunek zmian wysokości wydatków konsumpcyjnych powinien być zgodny z kierunkiem zmian dochodów rozporządzalnych netto, co pozwala oczekiwać dodatniej wartości oszacowań parametru $\alpha_{1}$. W świetle sformułowanej hipotezy oszacowania wartości parametrów $\alpha_{2}$ oraz $\alpha_{3}$ powinny być natomiast ujemne.

Mając na uwadze przytoczone wyniki badań Cecchetiego et al., negatywny wpływ zadłużenia sektora gospodarstw domowych na procesy wzrostu gospodarczego powinien ujawniać się w szczególności po przekroczeniu przez wskaźnik relacji tego zadłużenia do PKB progu $85 \%{ }^{23}$. Dążąc do zweryfikowania trafności tego wniosku w odniesieniu do tempa wzrostu wydatków konsumpcyjnych gospodarstw domowych jako kluczowej składowej PKB, w kolejnym etapie badania przeprowadziłem estymację modelu oddzielnie dla podgrup obserwacji, w których przedmiotowa relacja znajdowała się powyżej wyżej wymienionej wartości progowej oraz niższych lub równych tej wartości.

Badanie zostało przeprowadzone przy wykorzystaniu danych udostępnionych przez Organizację Współpracy Gospodarczej i Rozwoju w serwisie OECD, Stat (http://stats.oecd.org/) oraz przez Bank Rozrachunków Międzynarodowych w serwisie BIS, Statistics (http://stats.bis.org/).

Badana próba objęła 202 obserwacje z 29 krajów: Australii, Austrii, Belgii, Chile, Czech, Danii, Estonii, Finlandii, Francji, Grecji, Hiszpanii, Holandii, Irlandii Południowej, Japonii, Kanady, Korei Południowej, Łotwy, Niemiec, Norwegii, Polski, Portugalii, Słowacji, Słowenii, Stanów Zjednoczonych, Szwajcarii, Szwecji, Węgier, Wielkiej Brytanii oraz Włoch.

\section{Rezultaty empiryczne}

W tabeli 1 zostały przedstawione wyniki oszacowań parametrów skonstruowanego modelu dla całej próby badawczej.

23 S.G. Cecchetti et al., op.cit., s. 3. 
Tabela 1. Oszacowania parametrów modelu (wszystkie obserwacje)

\begin{tabular}{|c|c|c|c|c|c|c|}
\hline \multicolumn{7}{|c|}{ Model: $\widehat{\mathrm{CAGR}_{i t}}=\alpha_{0}+\alpha_{1} D_{I A G R_{i t}}+\alpha_{2} D_{-} N D I_{i t}+\alpha_{3} L_{T I R_{i t}}+\varepsilon_{i t}$} \\
\hline \multirow{2}{*}{$\begin{array}{l}\text { Parametr/ } \\
\text { Statystyka }\end{array}$} & \multirow{2}{*}{$\begin{array}{c}\text { Oszacowanie/ } \\
\text { Wartość }\end{array}$} & \multirow{2}{*}{ Błąd std. } & \multirow{2}{*}{$\begin{array}{l}\text { Statystyka } \\
\text { t-Studenta }\end{array}$} & \multirow{2}{*}{$\begin{array}{l}\text { Poziom } \\
\text { istotności }\end{array}$} & \multicolumn{2}{|c|}{ Wspótliniowość } \\
\hline & & & & & tolerancja & CIW \\
\hline$\alpha_{0}$ & 1,656 & 0,492 & 3,368 & 0,001 & & \\
\hline$\alpha_{1}$ & 0,590 & 0,055 & 10,699 & 0,000 & 0,761 & 1,314 \\
\hline$\alpha_{2}$ & $-0,005$ & 0,002 & $-2,290$ & 0,023 & 0,962 & 1,040 \\
\hline$\alpha_{3}$ & $-0,205$ & 0,070 & $-2,934$ & 0,004 & 0,735 & 1,360 \\
\hline$R^{2}$ & 0,505 & & & & & \\
\hline Statystyka F & 67,443 & & & 0,000 & & \\
\hline$N$ & 202 & & & & & \\
\hline
\end{tabular}

Źródło: Opracowanie własne.

Oszacowany model regresji okazał się istotny statystycznie. Wartość współczynnika determinacji wskazuje, że wahania dochodów rozporządzalnych netto, relacji zadłużenia do dochodów rozporządzalnych oraz długoterminowych stóp procentowych były łącznie w stanie wyjaśnić połowę zmienności tempa wzrostu popytu konsumpcyjnego w sektorze gospodarstw domowych badanych krajów. Niskie wartości czynników inflacji wariancji (CIW) nie wskazują na występowanie istotnej współliniowości wybranych zmiennych objaśniających.

Wszystkie parametry strukturalne modelu okazały się istotne statystycznie na poziomie 5\%. Zgodnie z oczekiwaniami zmiany tempa wzrostu dochodów rozporządzalnych netto były zgodne co do kierunku ze zmianami tempa wzrostu konsumpcji. Przeciętnie wzrost dochodów rozporządzalnych o 1 pkt proc. pociągał za sobą wzrost wydatków o 0,59 pkt. proc. Wyniki estymacji wskazują również na negatywny wpływ relacji zadłużenia do dochodów rozporządzalnych netto na tempo wzrostu konsumpcji. Oddziaływanie to wydaje się jednak stosunkowo słabe, gdyż wzrost wymienionej relacji o 1 pkt proc. pociągał za sobą przeciętnie spadek tempa wzrostu wydatków o 0,005 pkt. proc. Zdecydowanie silniejszy wpływ stwierdzono natomiast dla poziomu średnich długoterminowych stóp procentowych - ich wzrost (spadek) o 1 pkt proc. skutkował przeciętnie spowolnieniem (przyspieszeniem) tempa wzrostu wydatków o 0,205 pkt. proc. Uzyskane rezultaty wskazują zatem na istotny statystycznie ujemny wpływ zadłużenia na tempo wzrostu wydatków konsumpcyjnych gospodarstw domowych w badanym okresie, co przemawia za pozytywną weryfikacją sformułowanej hipotezy badawczej.

W kolejnym etapie badania została dokonana estymacja parametrów modelu dla podgrup obserwacji wyodrębnionych ze względu wartość relacji zadłużenia gospodarstw domowych do PKB. Wyniki estymacji modelu w podgrupie obserwacji 
o relacji zadłużenia sektora gospodarstw domowych do PKB nie wyższej od 85\% zostały przedstawione $\mathrm{w}$ tabeli 2.

Tabela 2. Oszacowania parametrów modelu (D/GDP $\leq 85 \%)$

\begin{tabular}{|c|c|c|c|c|c|c|}
\hline \multicolumn{7}{|c|}{ Model: $\widehat{\mathrm{CAGR}_{i t}}=\alpha_{0}+\alpha_{1} D I A G R_{i t}+\alpha_{2} D_{-} N D I_{i t}+\alpha_{3} L_{T I R_{i t}}+\varepsilon_{i t}$} \\
\hline \multirow{2}{*}{$\begin{array}{l}\text { Parametr/ } \\
\text { Statystyka }\end{array}$} & \multirow{2}{*}{$\begin{array}{c}\text { Oszacowanie/ } \\
\text { Wartość }\end{array}$} & \multirow{2}{*}{ Błąd std. } & \multirow{2}{*}{$\begin{array}{l}\text { Statystyka } \\
\text { t-Studenta }\end{array}$} & \multirow{2}{*}{$\begin{array}{l}\text { Poziom } \\
\text { istotności }\end{array}$} & \multicolumn{2}{|c|}{ Współliniowość } \\
\hline & & & & & tolerancja & CIW \\
\hline$\alpha_{0}$ & 1,469 & & 2,106 & 0,037 & & \\
\hline$\alpha_{1}$ & 0,653 & & 10,156 & 0,000 & 0,756 & 1,323 \\
\hline$\alpha_{2}$ & $-0,005$ & & $-1,119$ & 0,265 & 0,961 & 1,041 \\
\hline$\alpha_{3}$ & $-0,169$ & & $-2,051$ & 0,042 & 0,731 & 1,368 \\
\hline$R^{2}$ & 0,547 & & & & & \\
\hline Statystyka F & 56,381 & & & 0,000 & & \\
\hline$N$ & 144 & & & & & \\
\hline
\end{tabular}

Źródło: Opracowanie własne.

W porównaniu z oszacowaniami uzyskanymi dla całej zbiorowości obserwacji można zauważyć niewielki wzrost współczynnika determinacji przy zachowaniu istotności modelu oraz braku współliniowości zmiennych objaśniających. Co ciekawe, wartość parametru $\alpha_{2}$ w badanej podgrupie nie uległa zmianie w stosunku do oszacowania dla całej zbiorowości, przestała ona jednak być istotna statystycznie. Nadal istotny, choć słabszy niż w całej zbiorowości obserwacji, okazał się natomiast wpływ zmian poziomu długoterminowych stóp procentowych. W świetle tych rezultatów można stwierdzić, że przy zadłużeniu gospodarstw domowych nieprzekraczającym poziomu $85 \%$ PKB wzrost relacji tego zadłużenia do dochodów rozporządzalnych nie wywiera istotnego statystycznie negatywnego wpływu na tempo wzrostu wydatków konsumpcyjnych. Mimo że w analizowanej podgrupie obserwacji sam stopień obciążenia dochodów rozporządzalnych gospodarstw domowych długiem nie wydaje się znacząco oddziaływać na konsumpcję, to już zmiany wysokości jego oprocentowania mogą być uznane za istotną jej determinantę.

Wyniki estymacji parametrów modelu w podgrupie obserwacji, dla których relacja zadłużenia gospodarstw domowych do PKB przekroczyła 85\%, przedstawia tabela 3 .

W podgrupie obserwacji dla najsilniej zadłużonych sektorów gospodarstw domowych w analizowanym okresie zauważyć można wyraźny spadek dopasowania modelu do danych empirycznych. Oznacza to, iż w warunkach wysokiego zadłużenia gospodarstw domowych o kierunkach zmian popytu konsumpcyjnego w przeważającej mierze decydują czynniki inne niż dochody rozporządzalne netto, stopień zadłużenia czy długoterminowe stopy procentowe. Dodatkową przyczyną 
obserwowanego spadku zdolności predykcyjnej modelu mogła być również znacznie niższa niż w poprzednich analizach liczba obserwacji. Zarówno sam model regresji, jak i poszczególne jego parametry pozostały jednak istotne statystycznie na poziomie 5\%. Nie występowała także znacząca współliniowość zmiennych objaśniających.

Tabela 3. Oszacowania parametrów modelu (D/GDP > 85\%)

\begin{tabular}{|c|c|c|c|c|c|c|}
\hline \multicolumn{7}{|c|}{ Model: $\widehat{C A G R_{i t}}=\alpha_{0}+\alpha_{1} D_{I A G R_{i t}}+\alpha_{2} D_{-} N D I_{i t}+\alpha_{3} L T I R_{i t}+\varepsilon_{i t}$} \\
\hline \multirow{2}{*}{$\begin{array}{l}\text { Parametr/ } \\
\text { Statystyka }\end{array}$} & \multirow{2}{*}{$\begin{array}{l}\text { Oszacowanie/ } \\
\text { Wartość }\end{array}$} & \multirow{2}{*}{ Błąd std. } & \multirow{2}{*}{$\begin{array}{l}\text { Statystyka } \\
\text { t-Studenta }\end{array}$} & \multirow{2}{*}{$\begin{array}{l}\text { Poziom } \\
\text { istotności }\end{array}$} & \multicolumn{2}{|c|}{ Współliniowość } \\
\hline & & & & & tolerancja & CIW \\
\hline$\alpha_{0}$ & 3,343 & 1,073 & 3,115 & 0,003 & & \\
\hline$\alpha_{1}$ & 0,249 & 0,107 & 2,325 & 0,024 & 0,771 & 1,298 \\
\hline$\alpha_{2}$ & $-0,008$ & 0,004 & $-2,214$ & 0,031 & 0,934 & 1,070 \\
\hline$\alpha_{3}$ & $-0,384$ & 0,128 & $-3,010$ & 0,004 & 0,742 & 1,347 \\
\hline$R^{2}$ & 0,360 & & & & & \\
\hline Statystyka F & 10,125 & & & 0,000 & & \\
\hline$N$ & 58 & & & & & \\
\hline
\end{tabular}

Źródło: Opracowanie własne.

Silnie zadłużone sektory gospodarstw domowych cechowały się większą wrażliwością tempa zmian wydatków konsumpcyjnych zarówno na wysokość relacji całkowitego zadłużenia do dochodów rozporządzalnych netto, jak i poziom długoterminowych stóp procentowych. Wzrost każdej z tych zmiennych wywierał, ceteris paribus, istotny statystycznie negatywny wpływ na tempo wzrostu wydatków konsumpcyjnych. Stwierdzone różnice pomiędzy oszacowaniami parametru $\alpha_{2} \mathrm{w}$ obu analizowanych podgrupach można zatem uznać za argument wspierający wnioski sformułowane przez Cecchettiego et al.

Równolegle odnotowano silny spadek wrażliwości tempa zmian wydatków konsumpcyjnych na wahania poziomu dochodów rozporządzalnych netto, co można wyjaśnić faktem, iż najsilniej zadłużone sektory gospodarstw domowych występowały głównie w bogatych krajach rozwiniętych (Australii, Danii, Holandii, Kanadzie, Norwegii, Stanach Zjednoczonych, Szwajcarii, Wielkiej Brytanii) ${ }^{24}$, dla których niższa wrażliwość może być uzasadniona - sugerowanymi już przez J.M. Keynesa - wklęsłością funkcji konsumpcji względem bieżących dochodów oraz faktem, że popyt konsumpcyjny zamożnych społeczeństw może być w znacznym stopniu determinowany posiadanym majątkiem ${ }^{25}$.

24 W podgrupie tej znalazły się również Irlandia Południowa i Portugalia (w latach 2008-2013).

25 J.M. Keynes, Ogólna teoria zatrudnienia, procentu i pieniądza, przekład M. Kalecki, S. Rączkowski, Wydawnictwo Naukowe PWN, Warszawa 2012, s. 88. 


\section{Podsumowanie}

Wyniki przeprowadzonych analiz wskazują, że po wybuchu globalnego kryzysu finansowego zadłużenie sektora gospodarstw domowych w krajach OECD było jednym z czynników kształtujących dynamikę popytu konsumpcyjnego, a tym samym zachodzące w nich procesy wzrostu gospodarczego.

Zmiany relacji całkowitego zadłużenia do dochodów rozporządzalnych netto gospodarstw domowych w badanych krajach oddziaływały przeciwnie na tempo zmian ich wydatków konsumpcyjnych, choć wpływ ten można uznać za relatywnie niewielki. W całej poddanej analizie zbiorowości obserwacji wzrost (spadek) stopnia obciążenia dochodów rozporządzalnych długiem o 1 pkt proc. powodował bowiem przeciętnie spowolnienie (przyspieszenie) tempa wzrostu wydatków konsumpcyjnych o 0,005 pkt. proc. Efekt ten wyraźnie nasilał się po przekroczeniu przez całkowite zadłużenie sektora gospodarstw domowych w danym kraju poziomu 85\% PKB, podczas gdy poniżej tego progu przestawał on być istotny statystycznie. Przedstawione obserwacje są spójne z wnioskami Cecchettiego et al. dotyczącymi negatywnego wpływu zadłużenia gospodarstw domowych na procesy wzrostu gospodarczego po przekroczeniu wspomnianego progu.

Na podstawie przeprowadzonych badań stwierdziłem również istotną statystycznie ujemną zależność pomiędzy tempem zmian wydatków konsumpcyjnych gospodarstw domowych a wahaniami długoterminowych stóp procentowych, stanowiących kluczową determinantę faktycznych obciążeń dochodów rozporząadzalnych z tytułu zaciągniętych wieloletnich zobowiązań finansowych (zwłaszcza kredytów hipotecznych). Zjawisko to okazało się być istotne statystycznie zarówno w całej badanej zbiorowości, jak i w obu podgrupach wyodrębnionych ze względu na relację zadłużenia gospodarstw domowych do PKB. Podobnie jak w przypadku relacji zadłużenia do dochodów rozporządzalnych wpływ ten stawał się znacznie silniejszy po przekroczeniu przez zadłużenie sektora progu 85\% PKB.

Uzyskane wyniki wskazują zatem, że prowadzona przez wiele banków centralnych krajów OECD po wybuchu globalnego kryzysu finansowego ekspansywna polityka monetarna z jednej strony przyczyniała się do pobudzania popytu konsumpcyjnego poprzez kanał stopy procentowej, z drugiej jednak tempo wzrostu tego popytu mogło być hamowane w sytuacji jednoczesnego wzrostu relacji całkowitego zadłużenia gospodarstw domowych do ich dochodów rozporząadzalnych.

Biorąc pod uwagę uzyskane rezultaty, jak również istotność i złożoność problematyki wpływu zadłużenia gospodarstw domowych na procesy konsumpcji i wzrostu gospodarczego, zasadne wydaje się podjęcie dalszych prac badawczych w tym 
zakresie, polegających w szczególności na weryfikacji empirycznej oddziaływania jako zmiennych kontrolnych innych niż dochody rozporządzalne determinant popytu konsumpcyjnego, w tym zwłaszcza efektów związanych ze zmianami wartości majątku gospodarstw domowych.

\section{Bibliografia}

Aladangady A., Homeowner Balance Sheets and Monetary Policy, „Finance and Economics Discussion Series Working Paper” 2014, No. 2014-98, s. 1-40.

André C., Household debt in OECD countries: stylised facts and policy issues, „OECD Economic Department Working Papers" 2016, No. 1277, s. 1-39.

Baker S.R., Debt and the consumption response to household income shocks, „SSRN Research Paper" 2014, No. 2541142, s. 1-46.

„BIS Statistical Bulletin” June 2016.

Bogacka-Kisiel E., Finanse osobiste. Zachowania - Produkty - Strategie, Wydawnictwo Naukowe PWN, Warszawa 2012.

Bunn P., Household debt and spending, „Quarterly Bulletin” 2014, Q3, Bank of England, London, s. 304-315.

Cecchetti S.G., Mohanty M.S., Zampolli F., The real effects of debt, „BIS Working Papers” 2011, No. 352, s. 1-33.

Debelle G., Household debt and the macroeconomy, „BIS Quarterly Review” March 2004, s. 51-64.

Dynan K., Is a household debt overhangholding back consumption?, „Brookings Papers on Economic Activity" 2012, s. 299-362.

Finocchiaro D., Nilsson C., Nyberg D., Soultaneva A., Household indebtedness, house prices and the macroeconomy: a review of the literature. "Sverige Riksbank Economic Review" 2011, Vol. 1, s. 6-28.

Glick R., Lansing K.J., U.S. Household Deleveraging and Future Consumption Growth, „FRBSF Economic Letter” 2009, No. 16, s. 1-3.

Gruszecki T., Świat na długu, Wydawnictwo KUL, Lublin 2013.

http://stats.bis.org/statx/srs/table/F3.1? c=\&f=CSV

http://stats.oecd.org/

Justiniano A., Primiceri G.E., Tambalotti A., Household leveraging and deleveraging, „Review of Economic Dynamics" 2015, Vol. 18(1), s. 3-20.

Keynes J.M., Ogólna teoria zatrudnienia, procentu i pieniądza, przekład M. Kalecki, S. Rączkowski, Wydawnictwo Naukowe PWN, Warszawa 2012. 
Mian A., Rao K., Sufi A., Household balance sheets, consumption, and the economic slump, „The Quarterly Journal of Economics” 2013, Vol. 128(4), s. 1687-1726.

Lau Andersen A., Duus C., Jensen T.L., Household debt and consumption during the financial crisis: Evidence from Danish micro data, „Danmarks Nationalbank Working Papers” 2014, No. 89, s. 1-30.

Wachowski M., Wybrane aspekty zadłużenia gospodarstw domowych $w$ Polsce $w$ latach 2005-2012, „Marketing i Rynek” 2015, nr 2, s. 142-152.

Yao J., Fagereng A., Natvik G., Housing, debt and the marginal propensity to consume, „Norges Bank Research Paper" 2015, s. 1-38.

\section{Household indebtedness and dynamics of consumption spending in the oecd states since the beginning of the financial crisis}

The paper aims at empirical evaluation of the impact of household debt on the dynamics of consumption spending since the beginning of the global financial crisis. The research employed linear regression analysis of the rate of growth of household spending against the rate of growth of disposable income, the level of indebtedness and long-term interest rates in the OECD member states between 2008-2014. The results obtained indicate that household indebtedness was one of the factors influencing the dynamics of consumption demand and thus the processes of economic growth in the OECD states after the beginning of the global financial crisis. Variations in the relation of total debt to net disposable income and in the level of long-term interest rates were both negatively related to the changes in consumption spending. This impact turned out to be markedly stronger when total household debt of a given country was exceeding $85 \%$ of GDP, which is consistent with the results of previous investigations on the influence of the indebtedness of household sector on the dynamics of economic growth.

Keywords: households, indebtedness, consumption 


\section{Endettement des ménages et la dynamique des dépenses de consommation dans les pays d'OCDE après l'éclatement de la crise financière}

L'article vise à vérifier de façon empirique l'influence de l'endettement des ménages des pays de l'OCDE sur la dynamique de leur dépenses de consommation après l'éclatement de la crise financière globale. L'étude a été réalisée suivant la méthode de l'analyse de régression linéaire de la croissance des dépenses du secteur des ménages par rapport à la croissance du revenu disponible net, le niveau d'endettement, ainsi que des taux d'intérêt à long terme dans les pays de l'OCDE entre 2008-2014.

Les résultats obtenus suggèrent qu'après l'éclatement de la crise financière globale, l'endettement du secteur des ménages était l'un des facteurs influençant la dynamique de la demande de consommation et, par conséquent, la croissance économique dans les pays de l'OCDE. Les changements du rapport entre l'endettement total et le revenu disponible net, ainsi que les taux d'intérêt à long terme dans les pays analysés ont influencé de façon négative l'évolution des dépenses de consommation. Cette influence a visiblement augmenté après que l'endettement total du secteur des ménages du pays a dépassé $85 \%$ du PIB. Ces résultats paraissent cohérents avec les précédents concernant l'influence de l'endettement du secteur des ménages sur la dynamique de la croissance économique.

Mot-clés: ménages, endettement, consommation

\section{Задолженность домохозяйств и динамика потребительских расходов в странах ОЭСР после начала финансового кризиса}

Цель статьи состоит в эмпирической проверке влияния задолженности домохозяйств на динамику потребительских расходов после начала финансового кризиса. В исследовании использовался линейный регрессионный анализ темпов роста расходов домохозяйств против темпов роста располагаемого дохода, уровня задолженности и долгосрочных процентных ставок в странах ОЭСР в период 2008-2014 гг.

Полученные результаты указывают на то, что задолженность домохозяйств являлась одним из факторов, влияющих на динамику потребительских расходов и, следовательно, на процессы экономического роста стран ОЭСР 
после начала глобального финансового кризиса. Изменения в соотношении общей задолженности к располагаемому доходу и уровню долгосрочных процентных ставок оказали негативное влияние на темпы роста потребительских расходов. Это воздействие оказывалось значительно сильнее, когда общая задолженность домохозяйств данной страны превышала уровень 85\% ВВП, что согласуется с результатами предыдущих исследований о влиянии задолженности сектора домохозяйств на динамику экономического роста.

Ключевые слова: домохозяйства, задолженность, потребление 